\title{
The Legal Reform Policy on the Shariah Supervisory Board Role's in Indonesian Shariah Banks
}

\author{
Devi Triasari ${ }^{\mathrm{a}, 1, *}$, Francesco de Zwart ${ }^{\mathrm{a}, 2}$ \\ ${ }^{a}$ Faculty of Law, University Adelaide, Australia \\ ${ }^{1}$ devi.triasari@adelaide.edu.au*; ${ }^{2}$ francesco.dezwart@adelaide.edu.au \\ * corresponding author
}

\section{ARTICLE INFO}

Article history

Received: April 13, 2021

Revised: October 3, 2021

Accepted: October 30, 2021

\section{Keywords}

Legal Reform;

Shariah;

Bank;

\begin{abstract}
As Muslim majority country, Indonesia experiences the mushrooming of banks based on Islamic values (called shariah banking). The existence of sharia banking is followed by legal policies intended to support the progress of the business sector, including regulations regarding the Sharia Advisory Board, but the question is whether the policy is effective in the development of sharia banking in Indonesia. Adherent to that context, this study aims to examine the issues faced by the Sharia Supervisory Board in Indonesia. This study argues that there are at least fifth substantial problems related to the policies of the Sharia Supervisory Board in Indonesia, namely: (1) not all Shariah Supervisory Boards in Islamic business units have supported by a strong legal basis on which their operations are inducted to; (2) members of the Shariah Supervisory Board are appointed mostly based on their charisma and popularity in society, not of their knowledge and experience in related field; (3) ideally Shariah Supervisory Board must have recognized the banking system before becoming Shariah Supervisory Board, but the basic knowledge is not easy to understand when entering on technical issues; (4) many Shariah Supervisory Boards are not focused on shariah banks supervision duty because of their multi profession; (5) lack of advice related to product innovation and social needs issues.
\end{abstract}

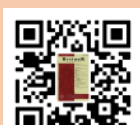

This is an open access article under the CC-BY 4.0 license.

\section{Introduction}

Based on a survey in 2010, the number of people who embraced Islam in the world was $1,723,607,136$. Even further, in 2060, Pew Research predicts that when population growth in the world is expected to reach $32 \%$ in the next few decades, Muslim population growth will increase by $70 \%$, from 1.8 billion in 2015 to get about 3 billion years in 2060. Thus, the rapid development of Islam is causing the development of banks that run on Islamic principles or so-called 'Shariah Banks' also which cannot be avoided. This can be seen from the increasing number of Shariah Banks throughout the world over the last four decades. Islamic countries and even non-Islamic countries are now starting to consider Shariah Banks to be applied in their respective jurisdictions. For example, the United Kingdom is the first western country to implement Shariah bonds. This was then followed by Germany who began launching Shariah Bank for the first time in 2016 (Saeed et al., 2021). Following this, Japan is seriously looking to consider implementing Shariah products. This is because Shariah Banks are believed to have advantages when compared to western banks. One of these advantages related to Islamic Banking is avoiding various kinds of losses in the 
financial crisis. The Shariah Banks strength' is believed due to restrictions on the types of bonds that are allowed based on Shariah principles.

Indonesia is a country with the most significant number of Muslims in the world. Even so, this fact does not make Indonesia an Islamic country that exclusively applies Shariah Law in the nation's life. If we look at history, Indonesia is a former Dutch colony that later gained its independence in 1945. This made Indonesia adopt the Dutch legal system known as civil law. Indonesia uses a civil law legal system where the important characteristic of this legal system is the codification of legislation. However, if it is found that the existing legislation is inadequate, legal reform is the best solution to benefit both for government and society. Indonesian legislation that implements the regulations and detail about Shariah Banks, particularly the Shariah Supervisory Board, is Law No. 21 of 2008 concerning Shariah Bank and its implementing regulations, which will be explained further in Chapter III (Juhro et al., 2020).

In addition to Indonesia's Act No. 21 of 2008, other countries also have a regulatory basis that regulates specifically related to the Sariah Banks. This has resulted in the regulation of Shariah Banks in a country often different from the arrangement of Shariah Banks in other countries. For the arrangements of Shariah Banks to have uniformity, the international standard is required. One of the international standards governing Shariah Banks can be found in the International Shariah Standards of the Accounting and Auditing Organization for Islamic Financial Institutions (AAOIFI). Indonesia itself, through its representatives from the Indonesian Ulema Council, is one of the Shariah Board members at the AAOIFI. The AAOIFI itself is an international non-profit organization founded in 1991 which has several missions, one of which is to provide guidelines for international Islamic financial practice based on the principle of Shariah. This study attempts to compare the regulation of the Shariah Supervisory Board in Indonesia and whether it meets the international standards set by AAOIFI. If not, then what kind of legal reform is needed for the future implementation of the Shariah Supervisory Board's Role in Shariah Banks to be more optimal (Wasiaturrahma et al., 2020).

Widespread in kinds of literature, the term 'Shariah Law' is a synonym of Islamic Law. Islamic Law itself is an integral part of Islamic Faith. If one embraces Islam, he or she will automatically be bound by Islamic Law because Islamic Law is kaffah (whole) and touches every dimension of the life of His adherents. But, in reality, when this Islamic legal system meets with other legal systems in a state jurisdiction, Islamic Law cannot be used in its entirety. For example, Indonesia is using the civil law system of former Dutch colonialism. Although most of the population of Indonesia embraces Islam, it does not necessarily cause Indonesia to use Islamic Law or cause Indonesia to become an Islamic state. Indonesia only uses Islamic Law in certain areas, such as marriage, inheritance, and Shariah. This is in line with the majority of legal scholars who say that the Islamic State is not only determined by demographics (where or not the people are adherents of Islam in a country) but includes whether or not and how its government use Shariah Law. Indonesia is a country with the most significant number of Muslim followers globally, but the Indonesian government does not exclusively use Islamic Law as a whole but in certain areas only (Qoyum et al., 2021).

\section{Results and Discussion}

\subsection{The Organizational Structure of Shariah Banking in Indonesia}

Before discussing more the organizational structure of Shariah banking in Indonesia, let us first review corporate governance, both single-tier and dual-tier. Corporate Governance (CG) explains the relationship between the various participants in the company, which determine the direction and performance of the company (Siswantoro, 2014). In a two-tier board system, the structure of corporate governance, called the board, is divided into two groups. The first group is called the supervisory board. This supervisory board consists of an independent non-executive director and a not independent non-executive director. The non-executive director does not carry out day-to-day operations within the corporation but has the same responsibilities as the executive director of corporate operations. Fig 1. Comparison of corporate governance of single-tier, dual-tier, and Shariah Banks in Indonesia. 


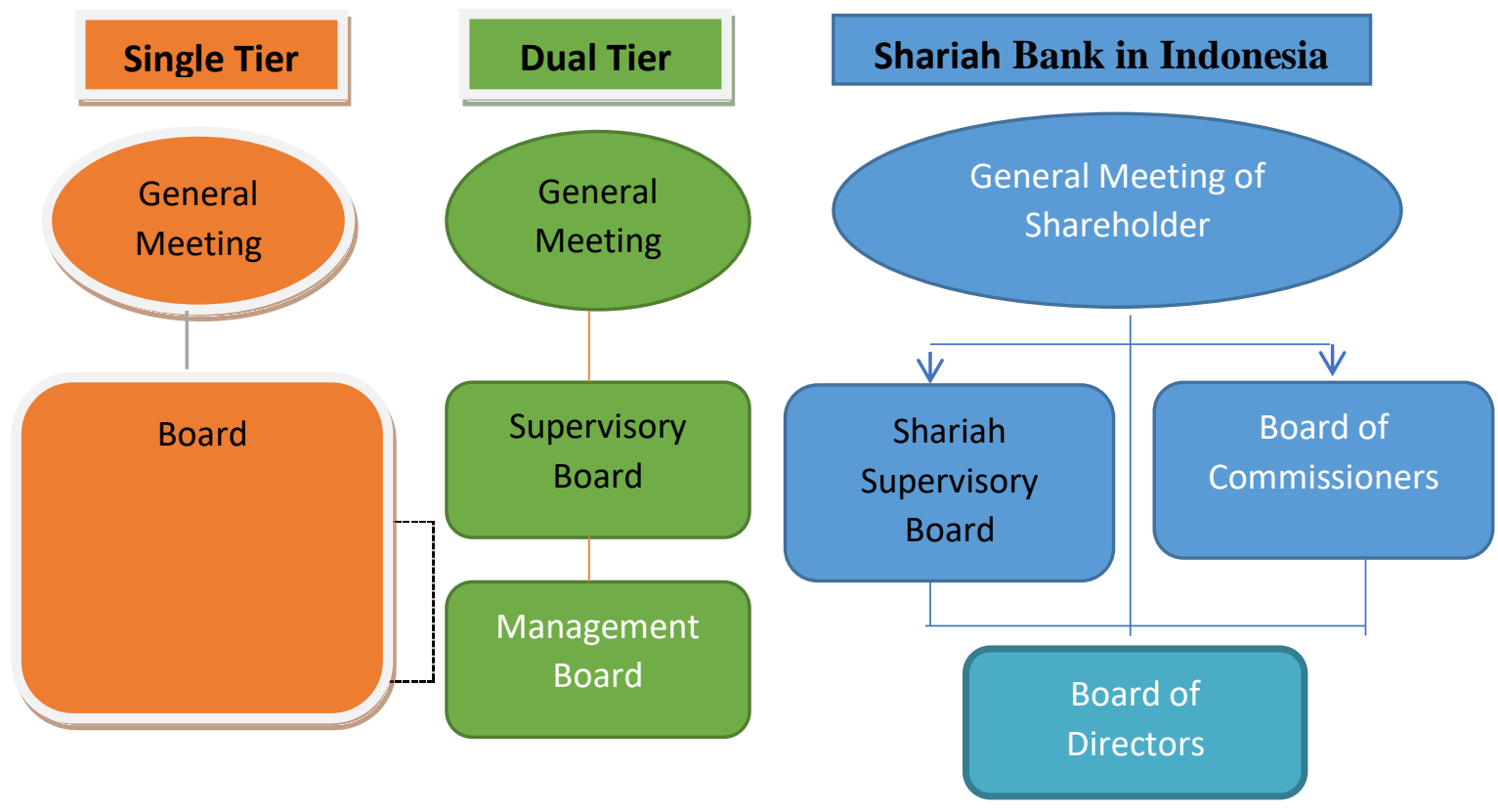

Fig. 1. Comparison of corporate governance of single tier, dual tier, and Shariah Banks in Indonesia.

Fig 1 show, in a one-tier board system, the role of the supervisory board and the implementing board are made in one. This is referred to as the board of directors. There are four types of board structures in a one-tier board system. The first type, all the executive directors, are board members. Top managers are also included as board members. This type of type is widely used by small companies, family companies, and start-up businesses. The second type, membership board of directors is filled by executive directors as members of the majority and non-executive directors as members of minorities. The third type is the opposite of the second type. The majority of board members are non-executive directors, some of whom are independent directors. In the latter type, all non-executive directors are board members. Non-profit organizations widely use this type of board. This structure is actually similar to a two-tier structure that is widely used by mainland European countries. Which corporations adopt models and systems in Indonesia. Indonesia's governance model can be considered to follow the European Continental pattern. Some of the features that refer to this system are, company law in Indonesia is adopted according to "French civil-law tradition" of Continental Europe, the use of two-tier board system structures as found in various Continental European countries, the concentration of ownership of the company to a group of people, dominant sources of financing companies from outside the company in the form of debt (external-bank financing), as well as the illiquidity of the capital market and the ineffectiveness of market control mechanisms.

\subsection{The Difference among Indonesian Ulema Council, National Shariah Board, and Shariah Supervisory Board Indonesia}

One of the differences between Shariah financial institutions and conventional financial institutions is the obligation of compliance fulfillment on Shariah principles. Every implementation of business activities in Shariah financial institutions must fulfill compliance with Shariah principles implemented in its products, services and operations. Compliance with Shariah principles is a form of contractual implementation in Shariah banking based on Shariah principles (Zuhroh et al., 2015). Every Shariah financial institution, especially Shariah banking, must have a reliable governance model and the right strategy to encourage the implementation of strong and effective corporate governance in Shariah environment. Another fundamental difference between a Shariah Bank and a conventional bank is the prohibition of interest on a Shariah Bank and the role of the Shariah Supervisory Board in each bank to oversee all forms of Shariah Bank operations (Shaban et al., 2014). 
In line with the development of Shariah financial institutions in the homeland, there is also a growing number of Shariah Supervisory Board to oversee each of these institutions. The variety of Shariah Supervisory Boards in each Shariah financial institution is something to be grateful for and to watch out for. The vigilance is related to the possibility of a different fatwa between the Shariah Supervisory Board and the other Shariah Supervisory Board. As an umbrella of Islamic institutions and organizations in Indonesia, the Indonesian Ulema Council considers the need to establish a National Shariah Board and oversees all institutions, including Shariah Banks (Trinugroho et al., 2018).

In Indonesia, the institution responsible for issuing fatwas in order that Shariah Bank meets Shariah principles is the National Shariah Board established by the Indonesian Ulema Council. The National Shariah Board was formed in 1997 and was the result of the recommendation of the Shariah Mutual Fund Workshop in July of the same year. This institution is autonomous under the Indonesian Ulema Council, led by the Chairman of the Indonesian Ulema Council and Secretary (ex-officio). The daily activities of the National Shariah Board are run by the Daily Executing Agency with a chairman and secretary as well as several members (Rizvi et al., 2020).

The more complex the problems faced by Shariah Financial Institutions are now demanding the increasingly alert of the National Shariah Board towards the innovations of products needed by the community. This is to promote and enhance the growth of Shariah Financial Institutions in the country. The National Shariah Board is an institution established by the Indonesian Ulema Council which has the function of performing the duties of the Indonesian Ulema Council in dealing with issues related to the activities of Shariah financial institutions. One of the main tasks of the National Shariah Board is to examine, explore and formulate the values and principles of Shariah law to be used as guidance in transaction activities in the Shariah financial institutions. Through the Shariah Supervisory Board oversees the implementation of Shariah principles in the system and management of Shariah financial institutions (Trinugroho et al., 2021).

The National Shariah Board is an independent institution in issuing fatwas as references related to economic, financial, and banking issues. The role of the National Shariah Board is crucial to improving Shariah banking and maintaining the compliance of Shariah banks against Shariah law. As of July 2007, the National Shariah Board has issued 61 Fatwa related Islamic financial products. The task of the National Shariah Board in the field of finance and banking is as an authority body providing advice to related institutions (Bank Indonesia, Ministry of Finance, or Investment Board) concerning the operations of Shariah banking or other Shariah financial institutions, coordinating Shariah issues on finance and Shariah banking, and analyzing and evaluating Shariah aspects of the scheme or new products proposed by other Islamic banking and finance institutions (Kamla \& Alsoufi, 2015).

To further streamline the role of the National Shariah Board on Shariah financial institutions, the Shariah Supervisory Board is established as the representative of the National Shariah Board at the relevant Shariah financial institution. Shariah Supervisory Board is a body authorized to supervise and closely observe the activities of Shariah financial institutions so that the institution will always follow the rules and principles of Shariah. Therefore, the Shariah Supervisory Board is basically a handshake of the National Shariah Board in realizing the fatwas decided by the National Shariah Board (Kamla \& Haque, 2019).

The Shariah Supervisory Board in Indonesia is appointed through the General Meeting of Shareholders on the recommendation of the National Shariah Board. In addition, the role of the National Shariah Board as an institution that has authority in issuing fatwas related to various forms of Shariah Financial Institution products, especially Shariah Banks, has an important role and must be supported with strong legal force. The Shariah Supervisory Board shall be owned by every bank operating its business under Shariah principles, whereby the Shariah Supervisory Board is an independent institution established by the National Shariah Board, and the Shariah Supervisory Board shall follow the fatwa issued by the National Shariah Board (Hassan \& Aliyu, 2018).

Shariah Supervisory Board acts as the supervisor of Shariah financial institutions, namely Shariah Banks, Takaful Insurance, Shariah Capital Market, etc., so that all institutions are following the demands of Shariah Law. Supervision in addition to aspects of Shariah financial products also 
includes management and administration of Shariah financial institutions to conform with Shariah. On the other hand, the Shariah Supervisory Board is a part of the Shariah financial institution concerned, which is placed on the approval of the National Shariah Board. The role of the Shariah Supervisory Board is to oversee the business activities of Shariah financial institutions to comply with Shariah principles and regulations which the National Shariah Board has filed. While, the main function are the first, as an advisor and adviser to the board of directors, head of Shariah business unit and head of Shariah branch office on matters relating to aspects of Shariah; and secondly, as a mediator between Shariah financial institutions and the National Shariah Board in communicating proposals and suggestions for product and service development from Shariah financial institutions (Lassoued et al., 2018).

In conducting its duties Shariah Supervisory Board is required to follow the fatwa of the National Shariah Board, oversee the business activities of Shariah financial institutions in order not to deviate from the Shariah rules and principles that have been filed by the National Shariah Board and report the business activities and the development of financial institutions regularly supervised to the National Shariah Board, at least twice a year (Bitar \& Tarazi, 2019). Thus, the Shariah Supervisory Board in the financial institution is obliged to direct, review and oversee the activities of financial institutions to be believed that they comply with the rules and principles of Shariah Law. The fatwa of the Shariah Supervisory Board binds the Shariah financial institution. Internally and normatively, to guarantee the jurisdiction of a Shariah financial institution, there is a provision that every Shariah financial institution is required to have Shariah Supervisory Board. In Shariah banks, the Shariah Supervisory Board is placed at one level with the Board of Commissioners at each Shariah bank. Such a position aims to make the Shariah Supervisory Board more authoritative and has the freedom of opinion in providing guidance and direction to all directors in the bank in cases related to the application of Shariah banking products. Therefore, the appointment of Shariah Supervisory Board members is conducted by the general meeting of shareholders of a shariah bank after the names of members of the Shariah Supervisory Board are approved by the National Shariah Board (Mollah \& Zaman, 2015).

After supervision, the Shariah Supervisory Board will make regular statements regarding the conformity of Shariah financial institutions with Shariah principles. Typically, published in the annual report of Shariah financial institutions concerned. In addition, the Shariah Supervisory Board also examines and recommends new products from institutions that are monitored in terms of conformity with Shariah principles, especially guidelines and fatwas issued by the National Shariah Board. Thus, the National Shariah Board is the agency authorized to establish and issue fatwas of Islamic Law regarding economic and financial activities. Meanwhile, the Shariah Supervisory Board is the institution responsible for overseeing the implementation of the fatwa of the National Shariah Board in the field by Shariah economic and financial institutions. Thus, the responsibility of the Shariah Supervisory Board organizationally is to the National Shariah Board, its credibility to the community and morally to Allah SWT.

In fact, supervising and directing Shariah financial institutions to encourage the implementation of Shariah principles in economic and financial activities is the task of the National Shariah Board domiciled in Jakarta. However, due to the limited number of its members and the increasing number of Shariah finance scattered throughout the archipelago, so its supervision is submitted to the Shariah Supervisory Board. The Shariah Supervisory Board is obliged to directly observe the implementation of a Shariah financial entity to not deviate from the provisions filed by the National Shariah Board. Shariah Supervisory Board sees the aspects of management and administration broadly should be in accordance with Shariah, and most of all legitimize and supervise the products of shariah banking in accordance with the provisions of Shariah and applicable law.

The Shariah Supervisory Board, which is the representative of the National Shariah Board placed in Shariah financial institutions, has the following roles following the fatwa of the National Shariah Board, formulate the issues that require the approval of the National Shariah Board, reporting business activities as well as the development of Shariah financial institutions that are supervised to the National Shariah Board at least once a year (Salem et al., 2021). The other roles of Shariah Supervisory Board in every Shariah financial institution are, provide advice to directors, head of Shariah business unit and head of shariah financial institution branch on matters relating to shariah 
aspect, conduct supervision, both actively and passively, especially in the implementation of the fatwa of the National Shariah Board and provide direction/supervision on products/services and business activities in accordance with the principles of Shariah, a mediator between Shariah financial institutions with the National Shariah Board in communicating proposals and suggestions of product and service development from Shariah financial institutions that require study and fatwa from the National Shariah Board.

In Bank Indonesia Circular Letter No.8/19/DPBS, it is formulated that the role of Shariah Supervisory Board are, to ensure and to monitor the suitability of bank operations against the fatwa issued by the National Shariah Board, to asses shariah aspects of operational guidelines and products issued by banks, to provide opinion of shariah aspect to the implementation of bank operation as a whole in bank publication report, to review new products and services for which there is no fatwa for fatwas to the National Shariah Board; and to submit reports on results of Islamic supervision. After obtaining a picture of the differences between the Indonesian Ulema Council, the National Shariah Board, and the Shariah Supervisory Board above, the diagrams below can further clarify the relationship of the three in their role in shariah banking in Indonesia.

\subsection{Comparison of the Position and Function of the Fatwa Institution in United Arab Emirates State}

If in Indonesia, the institution in charge of issuing fatwas in an institution is called Shariah Supervisory Board, and then in other countries there are various names that are used as follows table 1.

Table 1. Term used of Shariah Supervisory Board in Islamic Bank around the world

\begin{tabular}{cll}
\hline No. & \multicolumn{1}{c}{ Islamic Banks around the World } & \multicolumn{1}{c}{ Term used } \\
\hline 1 & Al-Baraka Islamic Investment Bank & Shariah Commitee \\
2 & Bank Islam Malaysia Berhad & Shariah Supervisory Cuncil \\
3 & Belt Ettanwil Tounsi Saudi, Tunisia & Shariah Advisor \\
4 & Dubai Islamic Bank & Shariah Supervisory Board \\
5 & El-Gharb Islamic Bank of Sudan & Shariah Supervisory Board \\
6 & Faisal Islamic Bank of Kibris Ltd. & Religius Supervisory Board \\
7 & Faisal Islamic Bank of Bahrain & Religius Supervisory Board \\
8 & Islamic Bank Bangladesh Limited & Shariah Council \\
9 & Islamic Bank of Bahrain & Religious Control Commitee \\
10 & Islamic Co-op Dev.Bank of Sudan & Shariah Supervisory Board \\
11 & Jordan Islamic Bank & Shariah Advisory Board \\
12 & Kuwait Finance House & Fatwa and Shariah Supervisory Authority Board \\
13 & Qatar International Islamic Bank & Religious Supervisory Committee \\
14 & Tadamon Islamic Bank of Sudan & Fatwa and Research Department \\
15 & Islamic Banks in Malaysia & Shariah Supervisory Council \\
16 & Islamic Banks in Pakistan & Shariah Board \\
17 & Islamic Banks in Uni Emirat Arab & Shariah Supervisory Board \\
18 & Islamic Banks in Indonesia & Shariah Supervisory Board \\
\hline
\end{tabular}

Table 1 shows, the after knowing the differences between the Indonesian Ulema Council, the National Shariah Board and the Shariah Supervisory Board in the previous section, as well as the use of different terms for the Shariah Supervisory Board in other countries, below are some examples of the status and function of fatwa institutions in other countries. The history of establishing Islamic Banks in Malaysia began with the establishment of Bank Islam Malaysia Berhad, which was established in 1983. The birth of Bank Islam Malaysia Berhad is also accompanied by the formation of Shariah Supervisory Council, whose job is to supervise Bank Islam Malaysia Berhad operations do not deviate from the provisions of Shariah Law. With the development of the Islamic banking system in Malaysia, Shariah Supervisory Council is also tasked to oversee the conventional banking that offered Shariah banking services in early 1993.

Along with the development of Shariah banking in Malaysia, the Malaysian government established the highest Shariah authority in Malaysia, namely National Shariah Advisory Council which was established on May 1, 1997. This institution serves as the holder of the highest authority in deciding Shariah issues in Shariah financial institutions, either bank or non-bank. The National 
Shariah Advisory Council is in the organizational structure of Bank Negara Malaysia. National Shariah Advisory Council members are appointed by the board of directors of Bank Negara Malaysia for a period of three years and may be re-elected in the following period. The purpose of the National Shariah Advisory Council was to act as the sole body of authority to advise BNM, relate to banking operations and Shariah Insurance, coordinate Shariah issues on Islamic finance and banking, including shariah insurance; and analyze and evaluate the Shariah aspects of the proposed new product or scheme by banking institutions and takaful companies (Abdullah et al., 2015).

With the establishment of the National Shariah Advisory Council, the duty of the Shariah Supervisory Council residing in Shariah financial institutions is only to oversee the operation of the financial institutions under its supervision as to whether it violates the guidelines and fatwas issued by the National Shariah Advisory Council. The existence of the National Shariah Advisory Council within the structure of the central bank will improve the responsiveness and effectiveness of decision-making and fatwas related to Shariah issues faced by Shariah banking and insurance. This is in contrast to Indonesia, where National Shariah Board is a non-governmental or independent institution. The establishment of the National Shariah Advisory Council in the structure of Bank Central in Malaysia has resulted in the limited independence of the Shariah council because it follows the rules of the government. The Shariah council is not a self-contained, independent institution but is under the board of directors of the central bank (Izzeldin et al., 2021).

The highest Shariah authority in finance and banking in Pakistan is in the Shariah Board. It is formed in the structure of the State Bank of Pakistan organization. Members of the Shariah Board are composed of two prominent Islamic scholars, an accountant, a lawyer, and a banker. The duties of the Shariah Board are not different from those of Shariah councils in general, among others: a) acting as the sole body of authority providing advice to the State Bank of Pakistan in relation to the operation of Shariah banking; b) coordinating Shariah issues on Shariah finance and banking, and c) analyze and evaluate the Shariah aspects of the new product scheme proposed by banking institutions.

The existence of Shariah Board within the central bank will improve the responsiveness and effectiveness of decision making and fatwas related to Shariah issues faced by Shariah banking. However, the independence of Shariah Board is limited also because it is not an independent institution and its members come from various disciplines. The structure of Shariah Board consists of several related fields, among others, Shariah experts, banking experts, accounting experts, lawyers and other experts. Shariah council consists of 5 people; the two are Shariah experts.

The United Arab Emirates State establishes the highest Shariah authority institution that serves as the stipulation of Shariah provisions from Shariah financial institutions. This institution was established under Article 5 of Federal Law No. 6 of 1985. The authority of this institution is as the holder of the highest Shariah power in the United Arab Emirates. Members of the Shariah Authority in the United Arab Emirates are not limited to becoming Shariah Supervisory Councils at the existing Sharia financial institutions in the country. Not much different from the fatwa institution in Indonesia which certain Islamic organizations also own, in United Arab Emirates countries, there are also many private Mufties. The number of Mufties gives freedom to the community to follow the mufti that they believe, or the Shariah financial institution is entitled to appoint its own Shariah Supervisory Board, without any recommendation from the State Fatwa Institution.

\subsection{Issue of Supervision of Shariah Supervisory Board in Shariah Bank}

According to Bank Indonesia research results with the cooperation of Ernst and Young has been discussed in one seminar at the end of 2008 at Bank Indonesia, one of the main problems in the implementation of risk management in Shariah Banks is the role of Shariah Supervisory Board which is not optimal and must be improved in the future. The role of Shariah Supervisory Board, if not optimal to Shariah compliance practice, resulted in the destruction of the image and credibility of Shariah Banks. This will affect public outlook and judgment, which may further undermine public confidence in Sariah Banks. Of the monitoring and inspection indicators reported by Bank Indonesia, there are still various operational systems of Shariah Banks that are not in compliance with the principles of compliance with Shariah values (Mateev \& Bachvarov, 2021). 
There are some of the weaknesses of the Shariah Supervisory Board in Indonesia. Firstly, not all Shariah Supervisory Boards in Islamic business units have a strong positive legal basis on which their operations are operational. The business units, only those in the form of Limited Liability Companies have a strong positive legal basis for the operation of Shariah Supervisory Board, namely Article 32 of Law No. 21 of 2008. In comparison, the positive legal basis related to the operation of the Shariah Supervisory Board in other business units does not yet exist. This absence is due to the lack of any law regulating such business units to operate in Shariah or the absence of further regulation by the authorities explaining the operational details of the Shariah Supervisory Board. The absence of clear legal and regulatory rules regarding its operations is certainly not a trivial matter. If this happens, it will certainly result in loss of public confidence to continue working and investing with shariah business units because it is possible to ignore the principles of Shariah by the manager of shariah business.

Secondly, members of the Shariah Supervisory Board are appointed because of their charisma and popularity in society, not because of their scholarship in economics and Shariah banking. Shariah, Supervisory Board members, are considered not fully understand the concept of Shariah economy, so the quality of supervision is questioned. Shariah financial institutions operate under different platforms with an Islamic worldview, while Islamic finance institutions also require new types of accounting and auditing. The distinction between Shariah audits and conventional audits is one of them lies in the aspect of Shariah which is the main basis of the implementation of Shariah audit which is not accommodated by conventional audit. Thirdly, in general, Shariah Supervisory Board must know the banking system since basic knowledge and debriefing before becoming Shariah Supervisory Board have been undertaken, but the basic knowledge is not easy to understand banking practices, especially when entering on technical issues, let alone to create a new product. In practice, the banks explain what is related to the problems and developments of banks, after that just discuss and resolve various banking problems.

Fourthly, many Shariah Supervisory Boards are not focused on supervision of Shariah Banks. One of them is due to having multiple positions both in government agencies such as lecturers and also due to activeness in other organizations. There are two issues related to the competence of Shariah auditors, first in terms of quality is the unequal competence of Shariah auditors in the knowledge of accounting and Shariah. Second, in terms of quantity that is still a limited number of Shariah auditors owned by Indonesia. As a country with a majority of its population is Muslim, the number of Shariah auditors owned is still very limited. In Indonesia alone, these audit practitioners are still looking for appropriate rule guidelines, framework regulation, as well as the competence and independence of Shariah auditors. Fifth, lack of advice related to product innovation and social needs issues. The current product is only murabaha and wakalah on murabahah. Previously there are also multi-service products but only some time. While in the issue of social good, banks only channeled the qard al-hasan funds and have never seen any further social problems.

\subsection{Optimizing the Role of Sharia Supervisory Board}

Based on the above issues, it is necessary to optimize the role of the Shariah Supervisory Board through legal reform. Firstly, the Shariah Supervisory Board of the Shariah business unit must have a strong positive legal basis to become its operational base. It should not be just a business unit in the form of limited liability company, which has a positive legal basis. The government needs to immediately establish a positive legal basis related to the operation of the Shariah Supervisory Board in other business units. The government should immediately issue arrangements for such business units to operate in Shariah like a business unit in the form of a Limited Liability Company. Secondly, Shariah Supervisory Board must primarily understand product knowledge in terms of Shariah provisions inherent in a product. Ideally, the Supervisory Board of Shariah, besides mastering Shariah principle also understood well the ins and outs of banking management. The Indonesian Ulema Council as the supreme body responsible for the fulfillment of Shariah principles shall determine the classification of the expertise of the parties who may be appointed to the National Shariah Board or the Shariah Supervisory Board. For example, in Sudan, members of the Department of Fatwa and Research and the Higher Shariah Supervisory Board are people who have expertise in Islamic jurisprudence, law and economics (accounting). For certain professions, certification is required to ensure competence and expertise in a particular field. For example, 
accountants and auditors are required by law to be certified as Certified Public Accountants (CPAs), or Certified Internal Auditors (CIAs). When Shariah audits require special skills and abilities, the competence requirements of auditors should also have a professional standard in the field of Shariah. Therefore, Shariah auditors must also have Shariah auditor certification or Certified Shariah Auditors to ensure that Shariah auditors are able to audit and ensure Shariah compliance. In this case, legal reform is needed in relation to the necessity of certification issuance of the parties who hold the positions of the National Shariah Board and Shariah Supervisory Board are really tested for their ability (Elamer et al., 2020).

Third, rules are needed to ensure that the Shariah Supervisory Board has the expected competence in conducting proper and effective oversight. In this case, it requires special competence in the field of banking or insurance and other fields. In addition, structural training is necessary for the Shariah Supervisory Board to understand the object of supervision so that the expected supervision is more effective and correct so that the practice is following or not following the principles of Shariah i.e. avoid maysir, gharar, riba and vanity. These requirements and training should be conducted strictly and systematically. Similarly, facilities support the supervision of whether related to the provision of information facilities and seminars regularly, especially to update information and insights about Shariah banking.

Organizational behavioral experts must have a concept of competence that is understood as a combination of skills and abilities. Ability to demonstrate stable characteristics is related to a person's maximum physical and mental abilities. Skill, on the other hand, is a unique capacity to manipulate an object. The world of formal or informal education has a strategic role in preparing Shariah auditors. Furthermore, this Shariah audit can be incorporated into the curriculum of the lecture so as to produce a double graduate of accounting and Shariah which raises the internalization of accounting and Shariah competencies. In addition, in the course can also be equipped with a debriefing of technical skills audit. The involvement of Shariah scholars is considered very important to participate in promoting Shariah audits. In this case the government needs legal reform related to the need for arrangements on the need to provide training to the Shariah Supervisory Board about practice on the field before serving in an institution. The requirement to become a Shariah Supervisory Board is regulated by Indonesian legislation appears to be insufficient detail, tend to be theoretical, and has not yet reached the provision of training to the Shariah Supervisory Board. In addition, the Indonesian government can also cooperate with both formal and non-formal education institutions that are able to provide graduates who compete theoretically and practically to become Shariah Supervisory Board.

Fourth, in the case of supervisory execution where it is found that the level of supervision intensity is less, this is evident from the level of the supervisory visit of the Shariah Supervisory Board to the Shariah Banks that are not in accordance with the rules that require minimal supervision done every month. One of the causes is the rush of the Shariah Supervisory Board, where most of the Shariah Supervisory Board has dual positions in other workplaces, so the Shariah Supervisory Board is impressed as "additional or side work". Inadequate supervision can lead to loopholes for banks to manipulate or discontinue bank activities, according to Shariah. Therefore, effective and measurable monitoring system breakthroughs with high intensity are required. The intensity of supervision is not sufficiently predicted with time limits, but supervision can ensure that every transaction runs according to shariah. The position of the Shariah Supervisory Board is not an additional but important and serious post.

Even if necessary, every transaction in a Shariah Bank must be witnessed directly by the Shariah Supervisory Board. This requires the government to carry out legal reforms related to the intensity of the Shariah Supervisory Board in conducting supervision of Shariah Banks that should be supplemented to really be able to monitor in detail the transactions conducted by shariah banks. In addition, the Indonesian government must limit the Shariah Supervisory Board not to double positions so that it can focus on its primary task to supervise Shariah banks in compliance with Shariah principles. In this case, Bank Indonesia, the government must immediately issue regulations or make changes on the existing legal basis to add legal reform. To the fifth, in the case of the new product development in Sharia Banks, the role of Shariah Supervisory Board is very minimal or can be called none. Almost all products offered are murabaha schemes. This indicates that the 
progressive role of the Shariah Supervisory Board to oversee and provide new or innovative inputs has not been well implemented.

In the practice setting, the Shariah Supervisory Board should understand that the needs of the developing community should be responded by the proper product stipulation in accordance with the definition contained in the National Shariah Board's fatwa on a product. In this context, Shariah Supervisory Board may encounter problems of choosing service products whose solution is disputed about its sophistication because it contains grey meanings. The expertise of the Shariah Supervisory Board, in this case, shall be tested, whether the customer's request is denied or accepted, determined by the depth of product knowledge in the definition of the fatwa of the National Shariah Board. The definition of Shariah operations relates to the certainty that all products offered and transactions executed by Shariah Banks are in accordance with the opinion of the Shariah Supervisory Board and the provisions of the National Shariah Board. Consequently, the competence of members of the Shariah Supervisory Board should always be honed properly. The government should be able to encourage the Shariah Supervisory Board to update its knowledge of Shariah Bank products to keep up with the times and not be inferior to the breakthroughs issued by conventional banks. Here the government needs to add regulation in order that the Shariah Supervisory Board should be able to provide innovation inputs to Shariah Banks.

Indonesia is the country with the highest number of Muslims in the world. This fact has resulted in many Shariah Banks scattered in Indonesia. Indonesian legislation discusses Shariah Banks, particularly with the Shariah Supervisory Board No. 21 of 2008 concerning Shariah Bank and its implementing regulations. The term Shariah Law is a synonym of Islamic law. There are four sources of Islamic law, namely, Al Qur'an, Hadith, Ijma, and Qiyas. Shariah Law has strict rules on what is prohibited based on Shariah principles, among others: usury is crueller than adultery, usury is destruction, all who are involved in usury will be cursed by Allah SWT, the perpetrators of usury will be entered into the river of blood, usury includes signs of the coming of the Day of Resurrection, be usury users will be threatened to become monkeys or pigs, usury is like the dangers of shirk, the usurers are mild like a man who married his own mother, users of usury likened someone who damages the Muslim honor, Allah will admit the perpetrators of usury, the treasure is a little though it looks a lot, and it can hinder from the forgiveness of Allah SWT According to theory, there are two types of corporate governance adopted by countries in the world, namely single board and dual board. Shariah banking in Indonesia certainly uses a dual board system. What is unique here is the existence of an institution called the Shariah Supervisory Board which specifically oversees the implementation of Shariah principles conducted by Shariah Banks. The Shariah Supervisory Board in Indonesia is responsible to the National Shariah Board established by the Indonesian Ulema Council, the highest clerical organization in Indonesia. The Shariah Supervisory Board, the National Shariah Board, and the Indonesian Ulema Council are responsible for overseeing the implementation of shariah principles in Indonesia. This Shariah Supervisory Board has many terms in other countries but has the same task to oversee the implementation of shariah principles by an institution.

The Shariah Supervisory Board under the AAOIFI (Accounting and Auditing Organization of Islamic Financial Institutions) has provided standards for Shariah Supervisory Board, composition, and related aspects such as regulations, reports and so on. AAOFI provides an overview of the implementation of this Shariah Standard in a guidebook published in November 2017. Below are 12 main points of Shariah Standard No. (29) AAOFI on the regulation of how fatwas can be issued in an institution that applies the principles of Shariah: Scope of the Standard, Definition of Fatwa and Istifta, Shari'ah Ruling on Fatwa and Istifta, Scope of Fatwa (Content), Conditions on Mufti Fatwa Issuers), Duties of the Institution That Seeks Fatwa, Methods and Means of Fatwa, Fatwa Controls, Text of Fatwa, Fatwa Manuscript (Document) Retreat from a Mistaken Fatwa, Morals of Fatwa (Ethics of Fatwa Issuers). Indonesia itself has several regulations relating to this Shariah Supervisory Board from the highest regulatory order in the form of law up to regulations issued by Bank Indonesia and the Financial Services Authority. These laws and regulations are Law Number 21 Year 2008, Law Number 40 Year 2007, PBI. 6/17/PBI/2004, PBI no.6/24/PBI/2004, PBI no.8/3/ PBI/2006, PBI no.11/33/PBI/2009, and the Financial Services Authority Regulation Number 30/ POJK.05/2014. After reviewing the existing legislation in Indonesia, starting from the law until the regulations issued by Bank Indonesia and the Financial Services Authority, basically the general 
description set by AAOFI has been applied in the legislation in Indonesia. No legislation is found that is directly contrary to Shariah Standard of AAOFI.

Meanwhile, the optimization of the role of the Shariah Supervisory Board that must be immediately carried out by the Indonesian government through legal reform are as follows: First, the government needs to immediately establish a positive legal basis related to the operation of the Shariah Supervisory Board to business units other than those in the form of Limited Liability Companies. The government should immediately issue arrangements for such business units to operate in Shariah like a business unit in the form of a Limited Liability Company. Secondly, the government needs to immediately conduct legal reform related to the need for certification issuance of the parties who hold the positions of the National Shariah Board, and Shariah Supervisory Board really tested its ability. Thirdly, the government needs legal reform with regards to the need for arrangements on the need to provide training to the Shariah Supervisory Board about practices on the ground before serving in an institution. In addition, the Indonesian government can also cooperate with both formal and non-formal education institutions that are able to provide graduates who compete both theoretically and practically to become Shariah Supervisory Board. Fourth, the government must immediately conduct legal reform related to the intensity of the Shariah Supervisory Board in supervising the Shariah Bank that should be supplemented so that it can really supervise in detail the transactions conducted by Shariah Banks. In addition, the Indonesian government must limit the Shariah Supervisory Board not to double positions so that it can focus on its main task to supervise Shariah Banks in compliance with Shariah principles. Fifth, the government should be able to encourage the Shariah Supervisory Board to update its knowledge of Shariah Bank products to keep up with the times and not be inferior to the breakthroughs issued by conventional banks. Here the government needs to add in order that the Shariah Supervisory Board should be able to provide innovation inputs to Shariah Banks.

\section{Conclusion}

There are several issues regarding Shariah Supervisory Board in Shariah Bank. Firstly, not all Shariah Supervisory Boards in Islamic business units have a strong positive legal basis on which their operations are operational. Of all the business units, only those in the form of Limited Liability Companies have a strong positive legal basis for the operation of Shariah Supervisory Board, namely Article 32 of Law No. 21 of 2008. Secondly, the Shariah Supervisory Board members are appointed for their charisma and popularity in society, not because of their knowledge in economics and Shariah banking. Thirdly, in general, Shariah Supervisory Board must know the banking system since basic knowledge and debriefing before becoming Shariah Supervisory Board have been undertaken, but the basic knowledge is not easy to understand banking practices, especially when entering on technical issues, let alone to create a new product. Fourthly, many Shariah Supervisory Boards are not focused on the supervision of shariah banks. One of them is due to having multiple positions both in government agencies such as lecturers and due to activeness in other organizations. Fifth, lack of advice related to product innovation and social needs issues.

\section{References}

Abdullah, W. A. W., Percy, M., \& Stewart, J. (2015). Determinants of voluntary corporate governance disclosure: Evidence from Islamic banks in the Southeast Asian and the Gulf Cooperation Council regions. Journal of Contemporary Accounting \& Economics, 11(3), 262-279. https://doi.org/10.1016/j.jcae.2015.10.001

Bitar, M., \& Tarazi, A. (2019). Creditor rights and bank capital decisions: Conventional vs. Islamic banking. Journal of Corporate Finance, 55, 69-104. https://doi.org/10.1016/j.jcorpfin.2018.11.007

Elamer, A. A., Ntim, C. G., Abdou, H. A., \& Pyke, C. (2020). Sharia supervisory boards, governance structures and operational risk disclosures: Evidence from Islamic banks in MENA countries. Global Finance Journal, 46, 100488. 
https://doi.org/10.1016/j.gfj.2019.100488

Hassan, M. K., \& Aliyu, S. (2018). A contemporary survey of islamic banking literature. Journal of Financial Stability, 34, 12-43. https://doi.org/10.1016/j.jfs.2017.11.006

Izzeldin, M., Johnes, J., Ongena, S., Pappas, V., \& Tsionas, M. (2021). Efficiency convergence in Islamic and conventional banks. Journal of International Financial Markets, Institutions and Money, 70, 101279. https://doi.org/10.1016/j.intfin.2020.101279

Juhro, S. M., Narayan, P. K., Iyke, B. N., \& Trisnanto, B. (2020). Is there a role for Islamic finance and R\&D in endogenous growth models in the case of Indonesia? Pacific-Basin Finance Journal, 62, 101297. https://doi.org/10.1016/j.pacfin.2020.101297

Kamla, R., \& Alsoufi, R. (2015). Critical Muslim Intellectuals' discourse and the issue of 'Interest' (ribā): Implications for Islamic accounting and banking. Accounting Forum, 39(2), 140-154. https://doi.org/10.1016/j.accfor.2015.02.002

Kamla, R., \& Haque, F. (2019). Islamic accounting, neo-imperialism and identity staging: The Accounting and Auditing Organization for Islamic Financial Institutions. Critical Perspectives on Accounting, 63, 102000. https://doi.org/10.1016/j.cpa.2017.06.001

Lassoued, N., Attia, M. B. R., \& Sassi, H. (2018). Earnings management in islamic and conventional banks: Does ownership structure matter? Evidence from the MENA region. Journal of International Accounting, Auditing and Taxation, 30, 85-105. https://doi.org/10.1016/j.intaccaudtax.2017.12.003

Mateev, M., \& Bachvarov, P. (2021). Regulation, ownership and bank performance in the MENA region: Evidence for Islamic and conventional banks. Emerging Markets Review, 47, 100789. https://doi.org/10.1016/j.ememar.2020.100789

Mollah, S., \& Zaman, M. (2015). Shari'ah supervision, corporate governance and performance: Conventional vs. Islamic banks. Journal of Banking \& Finance, 58, 418-435. https://doi.org/10.1016/j.jbankfin.2015.04.030

Qoyum, A., Sakti, M. R. P., Thaker, H. M. T., \& AlHashfi, R. U. (2021). Does the islamic label indicate good environmental, social, and governance (ESG) performance? Evidence from sharia-compliant firms in Indonesia and Malaysia. Borsa Istanbul Review. https://doi.org/10.1016/j.bir.2021.06.001

Rizvi, S. A. R., Narayan, P. K., Sakti, A., \& Syarifuddin, F. (2020). Role of Islamic banks in Indonesian banking industry: an empirical exploration. Pacific-Basin Finance Journal, 62, 101117. https://doi.org/10.1016/j.pacfin.2019.02.002

Saeed, S. M., Abdeljawad, I., Hassan, M. K., \& Rashid, M. (2021). Dependency of Islamic bank rates on conventional rates in a dual banking system: A trade-off between religious and economic fundamentals. International Review of Economics \& Finance. https://doi.org/10.1016/j.iref.2021.09.013

Salem, R., Usman, M., \& Ezeani, E. (2021). Loan loss provisions and audit quality: Evidence from MENA Islamic and conventional banks. The Quarterly Review of Economics and Finance, 79, 345-359. https://doi.org/10.1016/j.qref.2020.07.002

Shaban, M., Duygun, M., Anwar, M., \& Akbar, B. (2014). Diversification and banks' willingness to lend to small businesses: Evidence from Islamic and conventional banks in Indonesia. Journal of Economic Behavior \& Organization, 103, S39-S55. https://doi.org/10.1016/j.jebo.2014.03.021

Siswantoro, D. (2014). Analysis of Islamic Bank's Performance and Strategy After Spin-off as Islamic Full-fledged Scheme in Indonesia. Procedia - Social and Behavioral Sciences, 164, 41-48. https://doi.org/10.1016/j.sbspro.2014.11.048 
Trinugroho, I., Risfandy, T., \& Ariefianto, M. D. (2018). Competition, diversification, and bank margins: Evidence from Indonesian Islamic rural banks. Borsa Istanbul Review, 18(4), 349358. https://doi.org/10.1016/j.bir.2018.07.006

Trinugroho, I., Santoso, W., Irawanto, R., \& Pamungkas, P. (2021). Is spin-off policy an effective way to improve performance of Islamic banks? Evidence from Indonesia. Research in International Business and Finance, 56, 101352. https://doi.org/10.1016/j.ribaf.2020.101352

Wasiaturrahma, Sukmana, R., Ajija, S. R., Salama, S. C. U., \& Hudaifah, A. (2020). Financial performance of rural banks in Indonesia: A two-stage DEA approach. Heliyon, 6(7), e04390. https://doi.org/10.1016/j.heliyon.2020.e04390

Zuhroh, I., Ismail, M., \& Maskie, G. (2015). Cost Efficiency of Islamic Banks in Indonesia - A Stochastic Frontier Analysis. Procedia - Social and Behavioral Sciences, 211, 1122-1131. https://doi.org/10.1016/j.sbspro.2015.11.150 